\title{
Pengaruh Model Pembelajaran Recripocal Teaching Pair Share dengan Media Gambar Terhadap Kemampuan Berpikir Kritis Siswa SMA
}

\author{
Maria Apolonia Ndae ${ }^{1)}$, Diyah Ayu Widyaningrum ${ }^{2)}$ \\ ${ }^{1}$ Program Studi Pendidikan Biologi, Fakultas Ilmu Eksakta dan Keolahragaan, IKIP Budi Utomo \\ Email : antonhekaate@gmail.com \\ Email: diyahayuwidyaningrum8905@gmail.com
}
APA Citation: Ndae, M. A., Widyaningrum, D. A. (2020). Pengaruh Model Pembelajaran Recripocal Teaching Pair Share dengan Media Gambar Terhadap Kemampuan Berpikir Kritis Siswa SMA. Quagga: Jurnal Pendidikan dan Biologi, 12(1), 76-84. doi: 10.25134/quagga.v12i1.2297.

Received: 09-12-2019

Accepted: 20-01-2020

Published: 30-01-2020

\begin{abstract}
Abstrak: Pembelajaran mengggunakan model pembelajaran Recripocal Teaching Pais Share (RTPS) dengan media gambar dapat mempengaruhi kemampuan berpikir kritis siswa. Oleh karena itu, penelitian ini merupakan quasy experimentuntuk mengetahui pengaruh kemampuan berpikir kritis siswa SMA pada topik Sistem Pencernaan Makanan dan Pernapasan dengan menggunakan pembelajaran RTPS dengan media gambar. Data yang diambil adalah kemampuan berpikir kritis yang dinilai menggunakan rubrik. Teknik analisis data menggunakan uji anacova. Hasil penelitian menunjukkan $F$ hitung $<F$ tabel yaitu $0,000<0,05$ pada taraf signifikansi 5\% sehingga ada pengaruh model pembelajaran RTPS dengan media gambar terhadap kemampuan berpikir kritis siswa. Berdasarkan hasil analisis menunujukkan bahwa siswa dapat dilatih kemampuan berpikir kritisnya melalui sintaks RTPS. Model pembelajaran RTPS dengan media gambar berpengaruh terhadap kemampuan berpikir kritis siswa.
\end{abstract}

Kata kunci: pembelajaran; Reciprocal Teaching Pair Share; kemampuan berpikir kritis.

Abstract: Learning was the process of providing assistance and guidance to students to learn. The resulted of observation related learned biology at the Komba City High School showed that students had difficulty understanding the material of the digestive and respiratory systems with the difficulty of working on problems. Students have never been taught to used draw media by the teacher. Students have never been assessed critical thinking skill. Teachers used multistrategy and have not used learning model. The solution to these problems was used the Recripocal Teaching Pais Share (RTPS) learning model with image media determined their effect on students' critical thinking skills. This research was a quosy experiment with 2 variables. The data taken was the ability to think critically assessed using rubric. Data analysis technique used the Anacova test. The result showed the F count $<F$ table is $0,000<0.05$ at a significance level of 5\% so that there was an influence of the RTPS learning model with image media on students' critical thinking skills.

Keywords: learning; Reciprocal Teaching Pair Share; critical thinking skills.

\section{PENDAHULUAN}

Pembelajaran dapat dikatakan sebagai proses memberikan bimbingan atau bantuan kepada peserta didik dalam melakukan proses belajar (Aprida \& Dasopang, 2017). Pembelajaran biologi untuk siswa SMA diharapkan dapat mampu membekalkan kemampuan untuk beradaptasi dengan perubahan yang terjadi di lingkungan (Rustaman, 2011 dalam Sudarisman ,2015).
Selain itu pembelajaran biologi bertujuan untuk memberikan keterampilan proses sains mulai dari mengamati, mengelompokkan (klasifikasi), mengukur, menghitung, meramalkan, mengkomunikasikan, mengajukan pertanyaan (bertanya), menyimpulkan, mengontrol variabel, merumuskan masalah, membuat hipotesis, merancang penyelidikan, melakukan penyelidikan/percobaan. Setelah melakukan serangkaianketerampilan proses, 
Quagga: Jurnal Pendidikan dan Biologi

Volume 12, Nomor 1, Januari 2020, pp.76-84
p-ISSN 1907-3089, e-ISSN2651-5869

https://doi.org/10.25134/quagga.v12i1.2297 peserta didik akan mengkonstruk konsepkonsep materi biologi (Sudarisman, 2015). Sejalan dengan pendapat tersebut, berpikir didefinisikan sebagai pemikiran yang masuk akal dan reflektif yang berfokus untuk memutuskan apa yang mesti dipercaya atau dilakukan (Ennis dalam Nugraha, 2018). Sejalan dengan pendapat tersebut, (Halpern, 1998; Larsson, 2017 dalam Sulaiman \& Syakarofath, 2018) menyatakan bahawa berpikir krtis adalah upaya seseorang untuk memeriksa kebenaran dari suatu informasi menggunakan ketersediaan bukti, logika, dan kesadaran akan bias. Berpikir kritis sebagai suatu sikap untuk berpikir secara mendalam terkait masalah-masalah dan hal-hal yang berada dalam jangkauan pengalaman seseorang (Fisher, 2008 dalam Sulistiani \& Masrukan (2016). Berpikir kritis juga dapat didefinisikan sebagai pemikiran yang masuk akal dan reflektif yang berfokus untuk memutuskan apa yang mesti dipercaya atau dilakukan (Ennis, 1886 dalam Nugraha, 2018). Dalam pembelajaran biologi berpikir kritis adalah berpikir secara mendalam terhadap fenomenafenomena alam.

Pentingnya membekalkan berpikir kritis adalah memungkinkan siswa agar terbiasa menghadapi tantangan dan memecahkan masalah dengan menganalisis pemikirannya sendiri untuk memutuskan suatu pilihan dan menarik kesimpulan, sehingga tercetak para lulusan yang berkualitas dan mampu bersaing menghadapi tantangan (Sulistiani \& Masrukan, 2016). Muhfahroyin (2009) mengemuka-kan bahwa berpikir kritis penting bagi siswa agar menjadi pemecah masalah yang tangguh, pembuat keputusan yang matang, serta individu yang tidak pernah berhenti belajar. Peserta didik perlu menjadi seseorang yang mandiri sejalan dengan meningkatnya jenis pekerjaan di masa yang akan datang yang membutuhkan pekerja yang handal dan memiliki kemampuan berpikir kritis.

Selama proses pembelajaran kemampuan berfikir kritis peserta didik sebagai acuan dalam kognitif peserta didik yang diyakini akan menimbulkan pembelajaran yang berjalan aktif dan maksimal. Kemampuan berfikir kritis peserta didik sangat di perlukan di dalam pembelajaran salah satunya demi meningkatkan kepercayaan dan daya fikir (Diharjo, Budijanto, \& Utomo, 2017). Rendahnya kemampuan berpikir kritis siswa dapat menyebabkan siswa tidak dapat memecahkan permasalahan dalam kehidupan, tidak dapat membuat keputusan yang matang, malas belajar, kurang percaya diri serta berdaya fikir rendah.

Berdasarkan kondisi tersebut, guru biologi perlu membelajarkan bioogi dengan tepat, sehingga dapat menumbuhkan keterampilan berpikir kritis siswa SMA. Akan tetapi, berdasarkan hasil observasi mengenai proses pembelajaran yang terdapat di SMAN 2 Kota Komba menunjukkan bahwa siswa sulit memahami materi sistem pencernaan dan pernapasan. Selain itu masih banyak siswa yang belum tuntas dalam pembelajaran biologi. Guru belum pernah mengukur kemampuan berpikir kritis siswa. Kondisi ini diduga karena guru belum menggunakan model pembelajaran yang dapat melatihkan keterampilan berpikir kritis. Seperti disampaikan Muhfahroyin (2009) bahwa untuk membekalkan keterampilan berpikir kritis, guru perlu memilih pembelajaran yang tepat, terutama pembelajaran berpusat pada peserta didik melalui cooperative learning dan pembelajaran berpendekatan konstruktivistik. Selama ini, proses belajar mengajar, dengan kata lain guru hanya menggunakan multistrategi yaitu pembelajaran dengan menggunakan beberapa macam strategi misalnya demonstrasi dan diskusi. Guru juga belum menggunakan media yang relevan selama mengajar. Padahal media pembelajaran merupakan bagian penting dalam pembelajaran, terutama media yang digunakan sesuai dengan tujuan pembelajaran dan kebutuhan sehingga dapat melatihkan keterampilan berpikir kritis (Sudiantini \& Shinta, 2018). Media pembelajaran merupakan kebutuhan yang tidak dapat dielakkan dalam rangka menyukseskan proses belajar peserta didik agar dapat tercapai perubahan tingkah laku yang diharapkan (Mahnun, 2012).

Berkaitan dengan permasalahan tersebut, maka diperlukan perbaikan proses pembelajaran yang tepat agar guru Biologi dapat membekalkan keterampilan berpikir kepada siswanya. Terdapat berbagai model 
Quagga: Jurnal Pendidikan dan Biologi

Volume 12, Nomor 1, Januari 2020, pp.76-84
p-ISSN 1907-3089, e-ISSN2651-5869

https://doi.org/10.25134/quagga.v12i1.2297 pembelajaran, salah satunya Reciprocal Teaching Pair and Share (RTPS). RTPS merupakan model pembelajaran dengan langkah-langkah meliputi menyusun pertanyaan, memprediksi jawaban, mengklarifikasi jawaban, berpasangan (pair) dan mengkomunikasikan secara keseluruhan (share) serta merangkum (ringkasan) informasi- informasi penting dari teks bacaan dan merangkum hasil diskusi (Lestari \& Widyaningrum, 2016). Model RTPS juga dapat disertai dengan media pembelajaran, salah satunya media gambar. Media gambar termasuk jenis media visual. Media ini berfungsi untuk menyalurkan pesan dari penerima sumber ke penerima pesan. Media gambar sangat mengandalkan indera penglihatan (Haryanti, 2018).

Penelitian dengan menggunakan model pembelajaran RTPS dilakukan oleh (Lestari \& Wijayanti (2016) terhadap kemampuan metakognisi mahasiswa IKIP Budi Utomo pada matakuliah Mikrobiologi menunjukkan hasil yang signifikan. Huda, Susilo, \& Sa'dijah, (2017) melakukan penelitian mengenai penerapan pembelajaran Recripocal Teaching dipadu Think Pair Share dengan hasil dapat meningkatkan keterampilan berpikir kritis dan hasil belajar siswa kelas V. A, Corebima, \& Indriwati (2016) melalui penelitian dengan judul analisis pengaruh kebiasaan mengajar berdasarkan pembelajaran konvensional dalam memberdayakan metakognitif keterampilan dan keterampilan berpikir kritis siswa SMA di Malang, Indonesia dengan hasil peningkatan keterampilan metakognitif dalam pembelajaran konvensional adalah $60,582 \%$ lebih rendah daripada strategi pembelajaran TPS, $73,765 \%$ lebih rendah dari strategi pembelajaran RT, dan $112,886 \%$ lebih rendah dari TPS yang terintegrasi dengan strategi pembelajaran RT. Selain itu, peningkatan keterampilan berpikir kritis dalam pembelajaran konvensional adalah $60,737 \%$ lebih rendah daripada strategi pembelajaran TPS, 81,373\% lebih rendah dari strategi pembelajaran RT dan 133,898\% lebih rendah dari TPS yang terintegrasi dengan strategi pembelajaran RT.
Berdasarkan uraian diatas, dilakukan penelitian dengan judul Pengaruh Model Pembelajaran RTPS dengan Media Gambar Terhadap Kemampuan Berpikir Kritis Siswa. Adapun tujuan yang ingin di capai adalah mengetahui ada tidaknya pengaruh model pembelajaran RTPS dengan media gambar terhadap kemampuan berpikir kritis siswa. Materi yang digunakan dalam penelitian ini adalah sistem pencernaan dan sistem pernafasan. Materi ini merupakan materi yang berisi konsep-konsep abstrak yang sulit dipelajari oleh siswa.

\section{METODOLOGI PENELITIAN}

Metode penelitian yang digunakan dalam penelitian ini adalah eksperimental-semu (quasi experimental) yakni dengan memberi perlakuan terhadap situasi atau keadaan eksperimen yang ada tetapi tidak memberikan pengendalian secara penuh terhadap faktor- faktor eksternal yang dapat mempengaruhi eksperimen. Penelitian ini menggunakan pretest- postest control group design yang terdiri dari kelas kontrol dan kelas eksperimen. Pada kelas kontrol mendapat pembelajaran multistrategi yaitu pembelajaran dengan menggunakan beberapa macam strategi misalnya demonstrasi dan diskusi. Pada kelas kontrol pembelajaran dilakukan dengan strategi demonstrasi mengenai penyakit diare (untuk bab sistem pencernaan) dan bernafas (untuk bab sistem pernafasan), selanjutnya guru memberikan tugas membuat resume mengenai materi tersebut. Langkah selanjutnya adalah mendiskusikan mengenai resume. Pembelajaran dilakukan dengan 8 kali pertemuan. Pada kelas eksperimen mendapatkan model pembelajaran RTPS terhadap kemampuan berpikir kritis. Selain itu pada kelas eksperimen juga ditampilkan media gambar pada kegiatan awal pembelajaran serta kegiatan pada tahapan klarifikasi di sintaks model RTPS. Media gambar berupa gambar mengenai orang yang terkena diare, orang yang sedang merokok, sistem pencernaan makanan dan sistem pernafasan pada manusia. Media gambar orang yang terkenan diare dan orang yang sedang merokok ditunjukkan pada 
Quagga: Jurnal Pendidikan dan Biologi

Volume 12, Nomor 1, Januari 2020, pp.76-84
p-ISSN 1907-3089, e-ISSN2651-5869

https://doi.org/10.25134/quagga.v12i1.2297 saat kegiatan awal. Media gambar sistem pencernaan makanan dan sistem pernafasan pada manusia ditunjukkan pada saat tahap klarifikasi di sintaks RTPS. Sebelum perlakuan diberikan, terlebih dahulu kedua kelas diberikan pretest untuk mengetahui kemampuan awal. Tahap akhir penelitian ini pada masing-masing kelas diberikan postest untuk mengukur kemampuan berpikir kritis siswa setelah mendapat perlakuan.

Materi yang digunakan pada penelitian ini adalah sistem pencernaan makanan dan sistem pernafasan pada manusia. Indikator materi sistem pencernaan makanan meliputi menjelaskan mengenai zat-zat yang terkandung dalam bahan makanan, menjelaskan fungsi zat yang terkandung dalam bahan makanan, menganalisis uji makanan, menjelaskan organ pencernaan, menjelaskan fungsi organ pencernaan beserta enzim, mengurutkan proses pencernaan makanan, menganalisis penyakit yang berkaitan dengan sistem pencernaan. Indikator materi sistem pernafasan pada manusia meliputi menjelaskan organ pernafasan beserta fungsinya, membedakan macam-macam volume udara pernafasan, membedakan macam-macam pernafasan, mengurutkan mekanisme pernafasan, dan menganalisis penyakit yang berkaitan dengan sistem pernafasan pada manusia.

Populasi yang digunakan dalam penelitian ini adalah seluruh siswa kelas XI. Sampel yang digunakan dalam penelitian ini adalah 2 kelas, kelas XI IPA A sebagai kelas eksperimen dan kelas XI IPA B sebagai kelas kontrol dengan jumlah siswa pada masing- masing kelas 56. Variabel yang digunakan pada penelitian ini ada 2 macam yaitu variabel bebas dan variabel terikat. Variabel bebas yang digunakan adalah model pembelajaran RTPS dengan media gambar pada kelas eksperimen dan pembelajaran multistrategi pada kelas kontrol. Variabel terikat yang digunakan adalah kemampuan berpikir kritis.

Teknik pengumpulan data dalam penelitian ini adalah metode tes. Tes adalah serentetan pertanyaan atau latihan serta alat lain yang digunakan untuk mengukur keterampilan, pengetahuan, intelegensi, kemampuan atau bakat yang dimiliki oleh individu atau kelompok (Arikunto, 2006). Penelitian ini digunakan pretest dan posttest untuk mengukur kemampuan berpikir kritis dengan materi sistem pencernaan pada manusia dan sistem pernapasan pada manusia pada kelas eksperimen dan kontrol. Pretest digunakan untuk mengukur kemampuan awal kemampuan berpikir kritis siswa sebelum diberikan perlakuan dan posttest digunakan untuk mengukur kemampuan berpikir kritis siswa setelah diberikan perlakuan. Bentuk soal merupakan soal uraian dengan jumlah soal pretest adalah 6 soal dan jumlah soal posstest adalah 6 soal.

Instrumen yang digunakan dalam penelitian ini berupa rubrik tes kemampuan berpikir kritis siswa pada materi sistem pencernaan makanan pada manusia dan sistem pernapasan pada manusia yang akan dikenakan pada kelas eksperimen. Indikator kemampuan berpikir kritis meliputi memberikan penjelasan sederhana, membangun keterampilan dasar, menyimpulkan, memberikan penjelasan lanjut, dan mengatur strategi serta taktik .Langkahlangkah penyusunan perangkat tes dilakukan sebagai beriku: (1) Menentukan pembatasan materi yang diujikan yakni pada pokok bahasan mengenai sistem pencernaan makanan dan sistem pernapasan pada manusia, (2) Menentukan tipe soal yang digunakan yaitu soal uraian. (3) Menentukan jumlah butir soal. (4) Menentukan alokasi waktu yang dibutuhkan soal. (5) Membuat butir soal, kunci jawaban beserta pedoman penskoran. (6) Membuat lembar kerja siswa.

Penelitian ini dibutuhkan satu macam data, yaitu data mengenai kemampuan berpikir kritis data diperoleh mengunakan instrumen yang telah disiapkan. Pengumpulan data dilakukan dengan menggunakan dua kelas, yaitu kelas kontrol dan kelas eksperimen dan diberi pretest pada awal pembelajaran. Pada kelas eksperimen diberi perlakuan berupa model pembelajaran RTPS dengan media gambar sementara pada kelas kontrol digunakan multistrategi. Pada akhir 
Quagga: Jurnal Pendidikan dan Biologi

Volume 12, Nomor 1, Januari 2020, pp.76-84
p-ISSN 1907-3089, e-ISSN2651-5869

https://doi.org/10.25134/quagga.v12i1.2297 pembelajaran kedua kelas diberi posttest. Hasil dari tes ini digunakan untuk melihat kemampuan berpikir kritis siswa.

Teknik analisis data dalam penelitian ini dibagi menjadi tiga tahap, yaitu uji normalitas, uji homogenitas dan uji anacova.

\section{Analisis Data Awal}

Data yang dianalisis pada tahap awal dalam penelitian ini merupakan data nilai pretest biologi siswa kelas eksperimen dan kelas kontrol. Analisis data awal dilakukan untuk mengetahui bahwa sampel yang diambil mempunyai kondisi yang sama. Adapun uji yang dibutuhkan dalam analisis data awal berupa uji normalitas, uji homogenitas, dan uji Anacova. Data baik pretest mapun postest tidak dipisahkan berdasarkan materi melainkan 2 materi yaitu sistem pencernaan dan sistem pernafasan pada manusia berada dalam 1 tes.

\section{Uji normalitas}

Uji ini digunakan untuk mengetahui apakah data pretest dan posttest kelas eksperimen dan kelas kontrol berasal dari populasi yang berdistribusi normal atau tidak. Uji normalitas menggunakan uji statistik deskriptif program SPSS versi 16 menggunakan uji statistik Shapiro-Wilk untuk data $>30$, dan Kolmogrov-Smirnov untuk data $<30$.

\section{Uji homogenitas}

Uji homogenitas dilakukan untuk mengetahui apakah kedua kelompok mempunyai varians yang homogen atau tidak. Uji homogenitas menggunakan program SPSS versi 16.

\section{Uji Hipotesis}

Uji hipotesis dilakukan untuk mengetahui ada tidaknya pengaruh variable bebas terhadap variabel terikat. Metode pengujian terhadap hipotesis dilakukan secara parsial dengan menggunakan uji anacova. Uji anacova menggunakan Uji statistik deskriptif program SPSS versi 16.

\section{Kriteria keputusan}

Jika angka sig. > 0,05 maka H0 diterima, yang berarti tida ada pengaruh model pembelajaran Reciprocal Teaching Pair Share (RTPS) (X) secara simultan terhadap variabel terikat yaitu kemampuan berpikir kritis (Y). Jika angka Sig. < 0,05 maka H0 ditolak, yang berarti ada pengaruh model pembelajaran pembelajaran Reciprocal Teaching Pair Share (RTPS) (X) secara simultan terhadap variabel teerikat yaitu kemampuan berpikir kritis (X).

\section{HASIL DAN PEMBAHASAN}

Data yang diperoleh dari penelitian ini meliputi nilai kemampuan berpikir kritis siswa pada materi sistem pencernaan pada manusia dan sistem pernapasan pada manusia. Data berupa nilai pada 2 materi digabung. Data yang diperoleh dari kelas XI IPA-A sebagai kelas eksperimen dengan mengunakan model pembelajaran Reciprocal Teaching Pair Share (RTPS) dengan media gambar dan kelas XI IPA- B sebagai kelas kontrol di mana kelas menggunakan multistrategi. Data pretes dan postes untuk kelas kontrol dan kelas eksperimen disajikan secara berturut-turut pada tabel 1 dan tabel 2.

Tabel 1. Data Pretest dan Postest Kelas

\begin{tabular}{ccc} 
& Kontrol & \\
\hline Presensi & Pretest & Postest \\
\hline 1 & 28 & 74 \\
2 & 42 & 80 \\
3 & 22 & 65 \\
4 & 47 & 80 \\
5 & 19 & 66 \\
6 & 23 & 66 \\
7 & 40 & 80 \\
8 & 37 & 80 \\
9 & 17 & 62 \\
10 & 41 & 80 \\
11 & 34 & 76 \\
12 & 36 & 71 \\
13 & 39 & 79 \\
14 & 35 & 73 \\
15 & 36 & 80 \\
16 & 24 & 70 \\
17 & 45 & 81 \\
18 & 42 & 79 \\
19 & 29 & 75 \\
20 & 18 & 65 \\
21 & 25 & 75 \\
22 & 20 & 63 \\
23 & 30 & 78 \\
24 & 25 & 67 \\
25 & 39 & 79 \\
26 & 36 & 81 \\
27 & 34 & 74 \\
28 & 26 & 62 \\
\hline
\end{tabular}


Quagga: Jurnal Pendidikan dan Biologi

Volume 12, Nomor 1, Januari 2020, pp.76-84

Tabel 2. Data Pretest dan Postest Kelas

\begin{tabular}{|c|c|c|}
\hline \multicolumn{3}{|c|}{ Eksperimen } \\
\hline Presensi & Pretest & Postest \\
\hline 1 & 32 & 74 \\
\hline 2 & 42 & 80 \\
\hline 3 & 34 & 80 \\
\hline 4 & 27 & 74 \\
\hline 5 & 27 & 74 \\
\hline 6 & 44 & 89 \\
\hline 7 & 24 & 73 \\
\hline 8 & 34 & 77 \\
\hline 9 & 39 & 81 \\
\hline 10 & 41 & 81 \\
\hline 11 & 53 & 81 \\
\hline 12 & 58 & 90 \\
\hline 13 & 46 & 79 \\
\hline 14 & 41 & 76 \\
\hline 15 & 32 & 84 \\
\hline 16 & 30 & 80 \\
\hline 17 & 38 & 82 \\
\hline 18 & 48 & 85 \\
\hline 19 & 29 & 79 \\
\hline 20 & 36 & 82 \\
\hline 21 & 26 & 75 \\
\hline 22 & 55 & 90 \\
\hline 23 & 55 & 91 \\
\hline 24 & 30 & 88 \\
\hline 25 & 45 & 91 \\
\hline 26 & 24 & 72 \\
\hline 27 & 53 & 90 \\
\hline 28 & 44 & 83 \\
\hline
\end{tabular}

Data rekapitulasi hasil pretest dan postest kelas eksperimen disajikan pada tabel 3.

Tabel 3. Rekapitulasi Hasil Pretest dan Postest Kelas Eksperimen

\begin{tabular}{ccc}
\hline Nilai & Pretest & Posttest \\
\hline Terendah & 24 & 72 \\
Tertinggi & 58 & 91 \\
Rata-rata & 38,82 & 81,46 \\
\hline
\end{tabular}

Data rekapitulasi hasil pretest dan postest kelas kontrol disajikan pada tabel 4 .

Tabel 4. Rekapitulasi Hasil Pretest dan Postest Kelas Kontrol

\begin{tabular}{ccc}
\hline Nilai & Pretest & Posttest \\
\hline Terendah & 17 & 62 \\
Tertinggi & 47 & 81 \\
Rata-rata & 31,75 & 73,60 \\
\hline
\end{tabular}

Setelah didapatkan data pretest dan postest dilanjutkan dengan uji prasyarat. Uji prasyarat menggunakan uji normalitas dan uji homogenitas. Hasil uji normalitas disajikan pada tabel 5 .
p-ISSN 1907-3089, e-ISSN2651-5869

https://doi.org/10.25134/quagga.v12i1.2297
Tabel 5. Hasil Uji Normalitas

\begin{tabular}{|c|c|c|c|}
\hline & & Pretest & Posttest \\
\hline & $\mathrm{Sn}$ & 56 & 56 \\
\hline \multirow[t]{2}{*}{ Normal Parameters $^{2}$} & Mean & 35.2857 & 77.5357 \\
\hline & $\begin{array}{l}\text { Std. } \\
\text { Deviation }\end{array}$ & $\begin{array}{l}1.00828 \mathrm{E} \\
1\end{array}$ & 7.39278 \\
\hline \multirow[t]{2}{*}{$\begin{array}{ll}\text { Most } & \text { Extreme } \\
\text { Differences } & \end{array}$} & Absolute & .075 & .132 \\
\hline & $\begin{array}{l}\text { Positive } \\
\text { Negative }\end{array}$ & $\begin{array}{l}075 \\
-.050\end{array}$ & $\begin{array}{l}.106 \\
-.132\end{array}$ \\
\hline $\begin{array}{l}\text { Kolmogorov-Smirnov } \\
\mathrm{Z}\end{array}$ & & .561 & .988 \\
\hline $\begin{array}{llll}\begin{array}{l}\text { Asymp. } \\
\text { tailed) }\end{array} & \text { Sig. } & & \\
\end{array}$ & & .912 & .283 \\
\hline $\begin{array}{l}\text { A Test distribution is } \\
\text { Normal }\end{array}$ & & & \\
\hline
\end{tabular}

Berdasarkan uji normalitas diperoleh hasil F hitung $>$ F tabel yaitu 0,283 >0,05 pada taraf signifikasi 5\% sehingga $\mathrm{H} 0$ diterima, maka data berdistribusi normal. Uji homogenitas disajikan pada tabel 6 .

Tabel 6. Uji Homogenitas

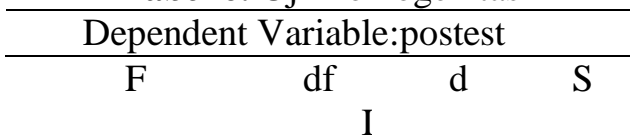

\begin{tabular}{llll}
\hline 107 & 1 & 5 \\
\hline
\end{tabular}

Berdasarkan uji homogenitas diperoleh hasil $\mathrm{F}$ hitung $>\mathrm{F}$ tabel yaitu $0,744>0,05$ pada taraf signifikansi $5 \%$ sehingga $\mathrm{H} 0$ diterima, maka data bersifat homogen. Data yang normal dan homogen selanjutnya dapat di uji lanjut menggunakan uji anacova. Uji anacova disajikan pada tabel 7 .

Tabel 7. Uji Anacova

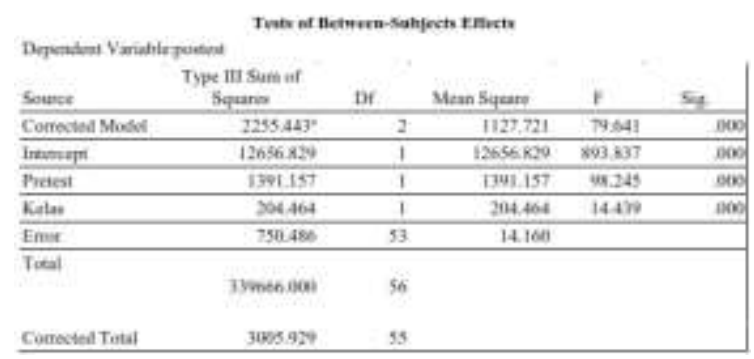

Berdasarkan tabel 5 diperoleh hasil $\mathrm{F}$ hitung $<\mathrm{F}$ tabel yaitu $0,000<0,05$ pada 
Quagga: Jurnal Pendidikan dan Biologi

Volume 12, Nomor 1, Januari 2020, pp.76-84
p-ISSN 1907-3089, e-ISSN2651-5869

https://doi.org/10.25134/quagga.v12i1.2297 taraf signifikansi 5\% sehingga ada pengaruh model pembelajaran RTPS dengan media gambar terhadap kemampuan berpikir kritis siswa.

Model pembelajaran RTPS memiliki sintaks meliputi siswa menyusun pertanyaan, siswa memprediksi jawaban, siswa mengklarifikasi jawaban, siswa berpasangan (pair), siswa mengkomunikasikan secara keseluruhan (share), siswa merangkum hasil diskusi (Lestari \& Widyaningrum, 2016). Saat pembelajaran berlangsung, media gambar ditampilkan di awal pembelajaran untuk memotivasi peserta didik dan merangsang pengetahuan awal peserta didik. Pada kegiatan inti dimulai dengan peserta didik diberikan artikel, lalu menyusun pertanyaan secara mandiri. Tahapan ini merupakan suatu konsep kemampuan berpikir kritis yang dikemukakan oleh (Ennis, 1885 dalam Diharjo et al., 2017) yang menjelaskan bahwasannya ada 6 konsep kemampuan berfikir kritis, salah satu diantaranya adalah merumuskan masalah (meliputi memformulasikan dalam bentuk pertanyaan untuk memperoleh jawaban). Selanjutnya peserta didik memprediksi jawaban secara individu. Langkah berikutnya peserta didik mengklarifikasi jawaban dengan membaca berbagai literatur dan mengamati media gambar untuk mencari jawaban pertanyaan. Prediksi dan klarifikasi merupakan suatu tahapan yang merangsang kemampuan berpikir kritis siswa seperti yang dikemukakan oleh Facione (1990) dalam Sulaiman \& Syakarofath (2018) bahwa berpikir kritis merujuk pada penilaian bertujuan untuk menghasilkan penafsiran, analisa, evaluasi dan kesimpulan, serta penjelasan atas bukti, konsep, metodologi dan kriteria atau pertimbangan-pertimbangan yang menjadi dasar dari penilaian. Penafsiran serupa dengan kegiatan prediksi dan klarifikasi dalam tahapan pembelajaran dengan model RTPS.

Tahapan berikutnya peserta didik berpasangan (pair), 1 kelompok terdiri dari 4 peserta didik. Selanjutnya peserta didik mempresentasikan jawaban (share) dalam bentuk diskusi kelas. Share merupakan bagian dari berpikir kritis sesuai dengan pendapat Johnson (2002) dalam Sulistiani \& Masrukan,
(2016) yang mengemukakan bahwa berpikir kritis merupakan kemampuan untuk berpendapat dengan cara terorganisasi, dan merupakan kemampuan untuk mengevaluasi secara sistematis bobot pendapat pribadi dan pendapat orang lain. Selama diskusi kelas berlangsung siswa dilatih kemampuan untuk berpendapat dan mengevaluasi pendapat pribadi serta pendapat orang lain. Tahapan terakhir pada pembelajaran menggunakan model RTPS adalah peserta didik merangkum materi yang telah dipelajari. Merangkum merupakan salah satu cara untuk menyimpulkan. Kegiatan membuat kesimpulan merupakan salah satu konsep berpikir kritis yang dikemukakan oleh (Facione, 1990 dalam Sulaiman \& Syakarofath, 2018).

Penelitian lebih lanjut mengenai model pembelajaran RTPS serta kemampuan berpikir kritis antara lain Lestari \& Wijayanti (2016) mengemukakan bahwa ada pengaruh model pembelajaran RT dipadu TPS terhadap kamampuan metakognisi mahasiswa IKIP Budi Utomo; Shophia \& Retno Mulyaningrum (2017) mengemukakan bahwa terdapat pengaruh yang signifikan pada model pembelajaran RT berbantu media pictorial riddle terhadap kemampuan berpikir kritis dan hasil belajar kognitif siswa pada materi keanekaragaman hayati; Tamara (2018) mengemukakan bahwa terdapat perbedaan kemampuan berpikir kritis siswa sebelum dan sesudah pembelajaran dengan penerapan metode Think-Pair-Share; Sundahry, Fitria, \& Rakimahwati, (2019) mengemukakan bahwa keterampilan berpikir kritis siswa yang diberi strategi reciprocal teaching lebih tinggi dibandingkan pembelajaran konvesional.

\section{SIMPULAN}

Berdasarkan hasil penelitian dan pembahasan, maka terdapat pengaruh model pembelajaran RTPS dengan media gambar terhadap kemampuan berpikir kritis siswa pada materi sistem pencernaan makanan dan sistem pernafasan pada manusia.

\section{REFERENSI}

A, Y. S., Corebima, D., \& Indriwati, S. E. 
Quagga: Jurnal Pendidikan dan Biologi

Volume 12, Nomor 1, Januari 2020, pp.76-84

(2016). The Analysis of Teaching Habit Effect Based on Conventional Learning in Empowering Metacognitive Skills and Critical Thinking Skills of Senior High School Students in Malang, Indonesia. International Journal of Academic Research and Development, 1(5), 6469.

Aprida, P., \& Dasopang, M. D. (2017). Belajar Dan Pembelajaran. FITRAH:Jurnal Kajian Ilmu-Ilmu Keislaman, 3(2), 333-352.

https://doi.org/10.24952/fitrah.v3i2.945

Diharjo, R. F., Budijanto, \& Utomo, D. H. (2017). Pentingnya Kemampuan Berfikir Kritis Siswa dalam Paradigma Pembelajaran Konstruktivistik. In Transformasi Pendidikan Abad 21 untuk Mengembangkan Pendidikan Dasar Bermutu dan Berkarakter (pp. 445-449). Malang.

Haryanti, A. S. (2018). Penggunaan Media Gambar dan Media Radio Pada Pembelajaran Menulis Deskripsi Siswa Kelas X SMA Tunas Harapan BalarajaTangerang. Jurnal Kredo, 1(2), 14-25. Retrieved from https://jurnal.umk.ac.id/index.php/kred o/article/viewFile/2108/1217

Huda, M. M., Susilo, H., \& Sa'dijah, C. (2017). Penerapan Pembelajaran Reciprocal Teaching Dipadu Think Pair Share Untuk Meningkatkan Keterampilan Berpikir Kritis Dan Hasil Belajar Siswa Kelas V. Jurnal Pendidikan, 2(10), 1356-1368.

Lestari, P. B., \& Widyaningrum, D. A. (2016). Pengembangan Model Pembelajaran Recripocal Teaching Pair and Share (RTPS) untuk Meningkatkan Hasil Belajar Mikrobiologi Mahasiswa IKIP Budi Utomo. Florea, 3(2), 15-24. https://doi.org/http://doi.org/10.25273/f lorea.v3i2.795

Lestari, P. B., \& Wijayanti, T. (2016). Pengaruh Model Reciprocal Teaching Dipadukan dengan Think Pair Share TerhadapKemampuan Metakognisi Mahasiswa MK Mikrobiologi IKIP
p-ISSN 1907-3089, e-ISSN2651-5869

https://doi.org/10.25134/quagga.v12i1.2297

Budi Utomo. JEMS (Jurnal Edukasi Matematika Dan Sains), 4(1), 1-7. https://doi.org/10.33503/paradigma.v22 i1.380

Mahnun, N. (2012). Media Pembelajaran (Kajian terhadap Langkah-langkah Pemilihan Media dan Implementasinya dalam Pembelajaran). Jurnal Pemikiran Islam, 37(1), 27-35. Retrieved from https://pdfs.semanticscholar.org/de8b/f b08d138cc2e8430b83e01b1e7c99117b $4 d 3$.pdf

Muhfahroyin. (2009). Memberdayakan Kemampuan Berpikir Kritis Siswa Melalui Pembelajaran Konstruktivistik. Jurnal Pendidikan Dan Pembelajaran (JPP), 16(1), 88-93.

Nugraha, W. S. (2018). Peningkatan Kemampuan Berpikir Kritis dan Penguasaan Konsep IPA Siswa SD dengan Menggunakan Model Problem Based Learning. Eduhumaniora : Jurnal Pendidikan Dasar, 10(2), 115127.

Shophia, A., \& Retno Mulyaningrum, E. (2017). Pengaruh Model Pembelajaran Reciprocal Teaching Berbantu Media Pictorial Riddle Terhadap Kemampuan Berpikir Kritis Dan Hasil Belajar Kognitif Siswa. BIOMA Jurnal Ilmiah Biologi, $6(1)$. https://doi.org/10.26877/bioma.v6i1.14 86

Sudarisman, S. (2015). Memahami hakikat dan Karakteristik Pembelajaran Biologi dalam Upaya Menjawab Tantangan Abad 21 Serta Optimalisasi Implementasi Kurikulum 2013. Florea, 2(1), 29-35. Retrieved from http://ejournal.unipma.ac.id/index.php/JF/artic le/viewFile/403/374

Sudiantini, D., \& Shinta, N. D. (2018). Pengaruh Media Pembelajaran Terhadap Kemampuan Berpikir Kreatif dan Penalaran Matematis Siswa. JPPM, 11(1), 177-186. Retrieved from http://150.107.142.250/index.php/JPP M/article/viewFile/2996/2327

Sulaiman, A., \& Syakarofath, N. A. (2018). 
Quagga: Jurnal Pendidikan dan Biologi

Volume 12, Nomor 1, Januari 2020, pp.76-84
p-ISSN 1907-3089, e-ISSN2651-5869

https://doi.org/10.25134/quagga.v12i1.2297

Berpikir Kritis: Mendorong Introduksi dan Reformulasi Konsep dalam Psikologi Islam. Buletin Psikologi, 26(2), 86-96. https://doi.org/10.22146/buletinpsikolo gi. 38660

Sulistiani, E., \& Masrukan. (2016). Pentingnya Berpikir Kritis dalam Pembelajaran Matematika untuk Menghadapi Tantangan MEA. In Seminar Nasional Matematika $X$ Universitas Negeri Semarang 2016 (pp. 605-612).

Tamara, T. (2018). Pengaruh Penerapan Metode Think Pair Share dan Group Investigation Terhadap Berpikir Kritis Siswa. Indonesian Journal Of Economics Education, 1(1), 73-84. https://doi.org/10.17509/jurnal 